\title{
ANALISIS SISTEM INFORMASI PENDAFTARAN DAN MONITORING SERVIS MOBIL PADA PT RESTU MAHKOTA KARYA CABANG KARAWANG
}

\author{
Rini Malfiany \\ STMIK Rosma Karawang, Manajemen Informatika \\ rini@rosma.ac.id
}

\begin{abstract}
ABSTRAK
PT Restu Mahkota Karya merupakan salah satu dealer resmi Suzuki di Kabupaten Karawang yang melayani servis kendaraan dan pembelian suku cadang. Setiap pelanggan yang akan melakukan servis kendaraan di PT Restu Mahkota Karya, harus medaftarkan kedaraannya terlebih dahulu.

Proses pendaftaran bisa dilakukan dengan cara datang langsung ke tempat pendaftaran bengkel PT Restu Mahkota Karya atau melakukan reservasi melalui layanan telepo dan pelanggan terkadang harus mencari atau bertanya kepada service advisor, begitu juga pelanggan yang menunggu atau meninggalkan kendaraan servis harus menelephone atau WhattApp untuk mengetahui perkembangan servis yang dilakukan terhadap kendaraannya. tentu hal ini tidak efektif karena pelanggan harus menelepon ataupun mendatangi langsung untuk bertanya kepada Servis Advisor.

Metode penelitian yang digunakan adalah metode SDLC dengan model waterfall dimulai dari analisis dan observasi terhadap sistem yang berjalan di PT Restu Mahkota Karya Cabang Karawang.

Dengan sistem informasi pendaftaran dan monitoring servis mobil yang diusulkan pelanggan dapat mengetahui sistem yang berjalan mengenai penyampaian informasi perkembangan proses servis yang berlangsung mulai dari pendaftaran sampai penyerahan kendaraan kepada pelanggan.
\end{abstract}

Kata kunci : pendaftaran, monitoring, service 


\section{PENDAHULUAN}

PT Restu Mahkota Karya merupakan salah satu dealer resmi Suzuki di Kabupaten Karawang yang melayani servis kendaraan dan pembelian suku cadang. Setiap pelanggan yang akan melakukan servis kendaraan di PT Restu Mahkota Karya, harus medaftarkan kedaraannya terlebih dahulu. Proses pendaftaran bisa dilakukan dengan cara datang langsung ke tempat pendaftaran bengkel PT Restu Mahkota Karya atau melakukan reservasi melalui layanan telepon. Dalam proses pendaftaran juga akan langsung ditentukan paket servis yang sesuai dengan kondisi kendaraan. Dimana terdapat empat paket servis yang disediakan dan setiap paket servis kendaraan menentukan suku cadang apa saja yang diganti serta item apa saja yang harus diperiksa.

Dalam proses bisnisnya, PT Restu Mahkota Karya sudah memiliki sistem informasi yang terhubung langsung ke kantor pusat dan kantor-kantor cabang lainnya yang tersebar di seluruh Indonesia. Sehingga semua transaksi sudah terkomputerisasi menggunakan aplikasi berbasis web. Namun sistem yang berjalan di PT Restu Mahkota Karya saat ini masih memiliki kekurangan yaitu reservasi/booking servis kendaraan yang masih mengandalkan layanan telepon sehingga berpotensi mengalami masalah-masalah teknis seperti waktu pendaftaran yang harus mengikuti aturan sesuai jam kerja, sehingga pelanggan yang hendak mendaftarkan kendaraannya lewat dari jam kerja, harus menunggu sampai hari kerja berikutnya. Masalah lainnya yang mungkin muncul ketika pelanggan melakukan servis kendaraan melalui layanan telepon adalah kendala yang disebabkan oleh masalah jaringan telepon. Terkadang telepon pelanggan tidak langsung tersambung dengan bagian pendaftaran bengkel PT Restu Mahkota Karya karena jaringan sibuk ketika telepon sedang digunakan. Informasi mengenai paket servis kendaraan yang tersedia juga kurang jelas diterima pelanggan bila disampaikan melalui layanan telepon, sehingga berpotensi menimbulkan kesalahan informasi (miss communication). Jika pelanggan meninggalkan mobilnya saat pengerjaan servis, pelanggan juga membutuhkan informasi sudah sejauh mana pengerjaan servis mobilnya, sehingga membutuhkan monitoring servis untuk membantu dalam kecepatan pelayanan servis yang optimal.

Berdasarkan permasalahan yang penulis uraikan di atas, penulis akan melakukan analisis lebih lanjut dalam penelitian ini dengan judul "Analisis Sistem Informasi Pendaftaran dan Monitoring Servis Mobil Pada PT Restu Mahkota Karya Cabang Karawang"

\section{TINJAUAN PUSTAKA}

Sistem informasi dapat didefinisikan dengan mengumpulkan, memproses, menyimpan, menganalisis, menyebarkan informasi untuk tujuan tertentu. Seperti sistem lainnya, sebuah sistem informasi terdiri atas input (data, instruksi) dan output (laporan, kalkulasi). (Sutarman, 2012:13)

Menurut (DEPDIKBUD01, 2012) pengertian pendaftaran adalah sebagai berikut : "Pendaftaran adalah proses, cara, perbuatan mendaftar yaitu pencatatan nama, alamat dsb dalam daftar ". Jadi, pendaftaran adalah proses pencatatan identitas pendaftar kedalam sebuah media penyimpanan yang digunakan dalam proses pendaftaran.

Monitoring/Pengontrolan dapat diartikan sebagai suatu aktivitas pengukuran dan koreksi dari kinerja untuk menjamin bahwa kegiatan dilakukan sesuai dengan rencana 
dan atau untuk mencapai tujuan yang diharapkan. (Sandu Siyoto dan Supriyanto, 2015:165),

Pelayanan atau servis menurut Mahmoedin (2010) adalah suatu aktivitas atau serangkaian aktivitas yang bersifat tidak kasat mata yang terjadi sebagai akibat adanya interaksi antara konsumen dengan karyawan atau hal - hal lain yang disediakan oleh perusahaan pemberi pelayanan yang dimaksud untuk memecahkan permasalahan konsumen/pelanggan.

\section{METODOLOGI PENELITIAN}

\subsection{Metode Pengembangan Sistem}

Metode pengembangan sistem yang digunakan penulis dalam penelitian ini adalah System Development Life Cycle (SDLC) waterfall yaitu proses pengembangan atau mengubah suatu sistem perangkat lunak dengan menggunakan model-model dan metodologi yang digunakan orang untuk mengembangkan sistem-sistem perangkat lunak sebelumnya berdasarkan best practice atau cara-cara yang sudah teruji baik. (Abdul Kadir, 2014).

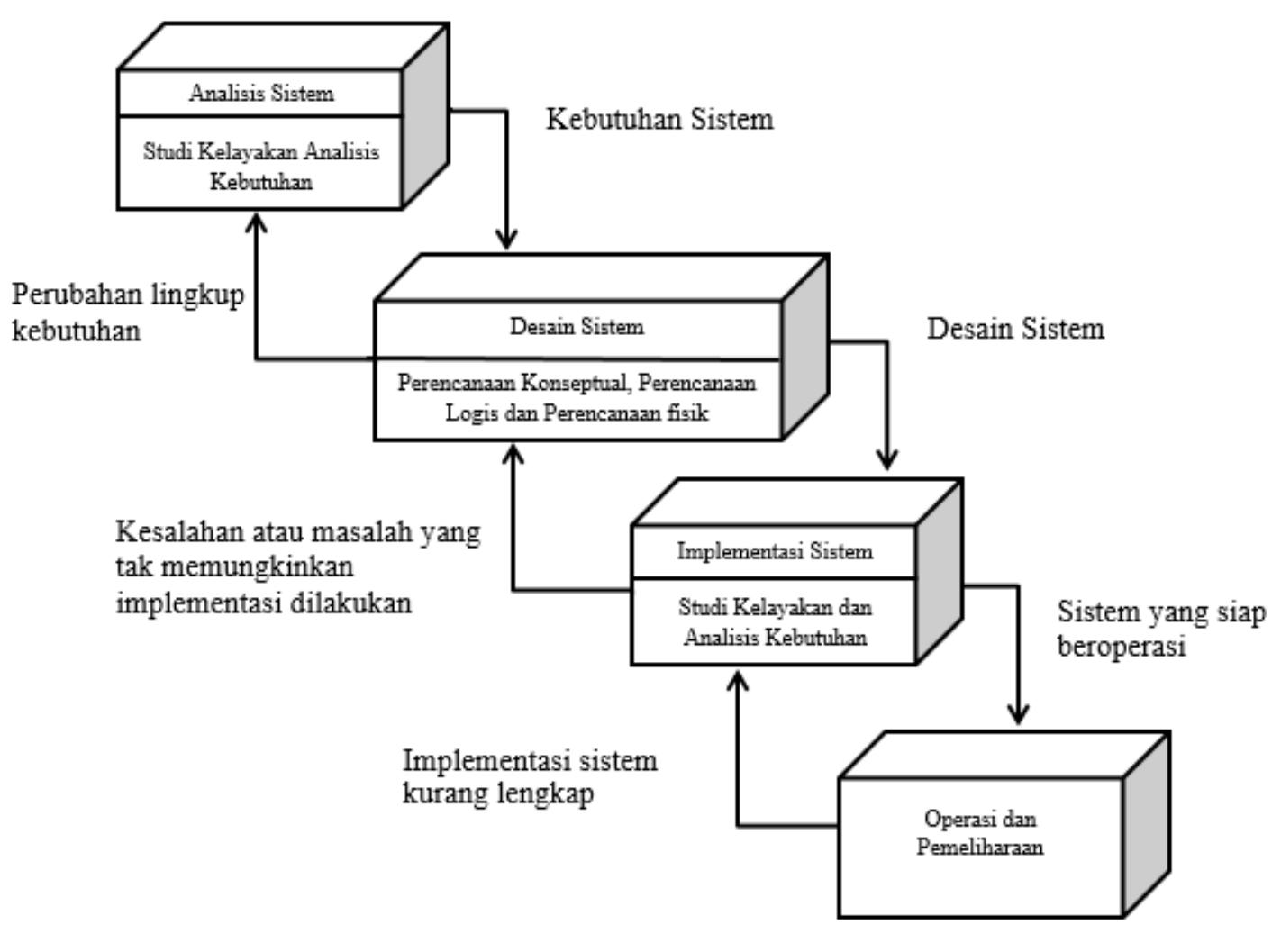

Gambar 1 Fase Waterfall

Sumber : Pengenalan Sistem Informasi Edisi Revisi. Abdul Kadir.2014.

Ada empat langkah yang dilakukan dalam pengembangan sistem ini, adalah sebagai berikut :

1. Analisis Sistem 
Pada tahap ini kegiatan yang dilakukan adalah untuk mengetahui ruang lingkup sistem, permasalahan yang dihadapi, kebutuhan pemakai, dan asumsi-asumsi pemecahan masalah.

Berikut ini adalah tahapan/kegiatan yang dilakukan dalam analisis sistem adalah :

a. Observasi

Observasi merupakan teknik pengumpulan data, dengan cara peneliti melakukan pengamatan langsung terhadap objek penelitian dengan mengamati kegiatan yang berhubungan dengan proses pendaftaran servic. Kegiatan yang dilakukan selama penelitian di PT restu Mahkota Karya Cabang Karawang.

b. Wawancara / Interview

Wawancara merupakan teknik pengumpulan data yang dilakukan penulis dengan cara tanya jawab. Penulis melakukan wawancara kepada Servis Advisor di PT Restu Mahkota Karya yaitu Bapak Sutedja, S.Kom. dan penulis juga melakukan wawancara dengan konsumen guna mendapatkan lebih banyak informasi mengenai proses pendaftaran servis mobil.

c. Studi Pustaka

Pengumpulan data dengan menggunakan atau mengumpulkan dari sumber-sumber tertulis, dengan cara membaca, mempelajari dan mencatat hal-hal penting yang berhubungan dengan penulisan laporan ini.

d. Dokumentasi

Dilakukan dengan mengumpulkan dokumen yang berhubungan dengan sistem informasi pendaftaran servis mobil.

2. Desain Sistem

Metode perancangan yang akan digunakan oleh penulis dalam menyusun dan merancang sistem informasi pendaftaran servis mobil, mencakup perancangan flow document.

3. Implementasi Sistem

Tahapan ini dilakukan implementasi rancangan sistem dengan bahasa pemrograman (PHP), penelusuran kesalahan (Debugging), uji coba menggunakan black box testing dan instalasi sistem.

4. Pemeliharaan Sistem

Pemeliharaan sistem dapat berupa penataan database, back up, scanning virus, dan tindakan-tindakan penyesuaian untuk menjaga sistem dan perbaikan terhadap kesalahan yang sebelumnya belum pernah terjadi maupun yang sudah terjadi.

\subsection{Metode Analisis Sistem}

Dalam menganalisis sistem infromasi pemesanan garment, penulis menggunakan metode analisis SWOT. Menurut Abdul Kadir (2014:416), analisis SWOT mengandung empat bagian yaitu, Strengths $(S)$ atau kekuatan, Weaknesess $(W)$ atau kelemahan, Opportunities $(O)$ atau peluang, dan Threats $(T)$ atau ancaman.

Berikut adalah penjelasan mengenai analisis SWOT di PT Restu Mahkota Karya Cabang Karawang yaitu :

1. Kekuatan (Strengths) 
Analisis kekuatan pada PT Restu Mahkota Karya Cabang Karawang yaitu dalam kegiatan usahanya memberikan pelayanan jasa servis kepada pelanggan.

a. Memiliki pelanggan tetap.

Karena perusahaan ini telah berdiri sejak tahun 1988, PT Restu Mahkota Karya memiliki beberapa pelanggan tetap yang mempercayakan servis mobilnya kepada PT Restu Mahkota Karya Cabang Karawang.

b. Memiliki karyawan dengan skill terlatih.

Hal ini terlihat di mana karyawan mampu menggunakan sistem/alat dalam memberikan proses pelayanan dan karyawan mengetahui riwayat kendaraan yang akan diservis.

c. Memiliki alat-alat pengerjaan servis yang canggih.

Hal ini menjadi salah satu keunggulan bagi PT Restu Mahkokta Karya Cabang Karawang karena kerusakan mobil bisa terdeteksi dengan sistem.

d. Sistem yang akan diusulkan dapat mempercepat proses pendaftaran.

Karena banyaknya pelanggan yang mendaftar servis dan juga kesibukan para pelanggan untuk datang langsung, maka pelanggan dapat mendaftar terlebih dahulu melalui sebuah sistem aplikasi tanpa harus mengantri untuk mendaftarkan servis mobil juga pelanggan dapat mengetahui status mobil nya yang sedang atau pun telah selesai diservis.

2. Kelemahan (Weaknesess)

a. Pada sistem yang berjalan sering pelanggan harus datang untuk mengantri pendaftaran servis, jika melalui telepon tidak akan maksimal karena melalui telepon terkadang tidak jelas dan sering terputus sambungannya.

3. Peluang (Opportunities)

a. Kapasitas servis dengan jumlah banyak.

Dengan jumlah karyawan servis advisor sebanyak empat orang dan mekanik berjumlah lima belas orang, maka kapasitas jumlah servis bisa bertambah setiap harinya.

b. Melakukan pelatihan secara berkala agar para karyawan yang memiliki skill tetapi belum optimal di bidangnya masing-masing dapat mengembangkan dan meningkatkan kemampuan yang telah mereka miliki sehingga dapat memberikan hasil pelayanan yang lebih maksimal.

c. Peluang dibuatnya sistem dapat mempermudah dan mempercepat proses pendaftaran dan monitoring servis mobil.

4. Ancaman (Threats)

a. Meningkatnya persaingan bengkel servis dengan merk yang sama seperti Citra Buana Asih.

b. Menurunnya tingkat daya servis mobil, karena kebutuhan ekonomi yang semakin tinggi.

\section{HASIL PEMBAHASAN}




\subsection{Prosedur pendaftaran servis reguler}

E ISSN : 2580-5517

Sebelum melakukan servis, semua pelanggan harus mendaftarknan kendaraannya terlebih dahulu pada bagian pendaftaran. Bagi pelanggan yang belum pernah melakukan servis kendaraan di PT Restu Mahkota Karya Cabang Karawang sebelumnya, pelanggan harus memberikan informasi data pelanggan dan kendaraan yang akan diservis kepada petugas pendaftaran yang sedang bertugas, berikut ini adalah prosedur pedaftaran servis kendaraan di PT Restu Mahkota Karya:

1. Pelanggan menghubungi petugas pendaftaran dengan datang secara langsung ke bagian pendaftaran servis PT Restu Mahkota Karya.

a. Untuk pelanggan baru, ketika akan daftar pelanggan langsung di arahkan untuk mengisi data pelanggan dan data kendaraan yang akan di servis untuk disimpan dalam database pelanggan servis kendaraan PT Restu Mahkota Karya. Setelah data pelangan tersimpan, kemudian petugas pendaftaran melakukan proses input data pendaftaran servis kendaraan untuk pelanggan tersebut.

b. Bagi pelanggan yang sudah terdaftar dan tersimpan datanya dalam sistem, ketika melakukan pendaftaran petugas akan menannyakan nomor polisi kendaraan dan langsung menginputnya dalam sistem pendaftaran. Karena dengan nomor polisi kendaraan, data pelanggan secara langsung muncul, sehingga petugas hanya perlu memvalidasi atau memastikan data pelanggan yang terpilih sesuai dengan pelanggan yang melakukan pendaftaran.

2. Setelah data pendaftaran tersimpan kedalam sistem, maka data tersebut selanjutnya akan di follow-up oleh servis advisor sesuai nomor pendaftaran.

3. Servis advisor memanggil pelanggan secara bergantian, untuk menanyakan kondisi kendaraan kemudian merubah status pendaftaran pada sistem menjadi close (sudah dikerjakan).

4. Pelanggan memberikan informasi kondisi kendaraan.

5. Servis advisor menyarankan paket servis yang sesuai dengan kondisi kendaraan yang diinformasikan pelanggan.

6. Servis advisor membuat Surat Perintah Kerja (SPK) sebagai acuan mekanik untuk melakukan servis.

7. SPK yang sudah dibuat dicetak tiga rangkap dan diberikan kepada bagian sparepart, foreman dan pelanggan.

Berikut diagram alur proses pendaftaran servis kendaraan regular di PT Restu Mahkota Karya: 
ISSN : 2541-6995

E ISSN : 2580-5517

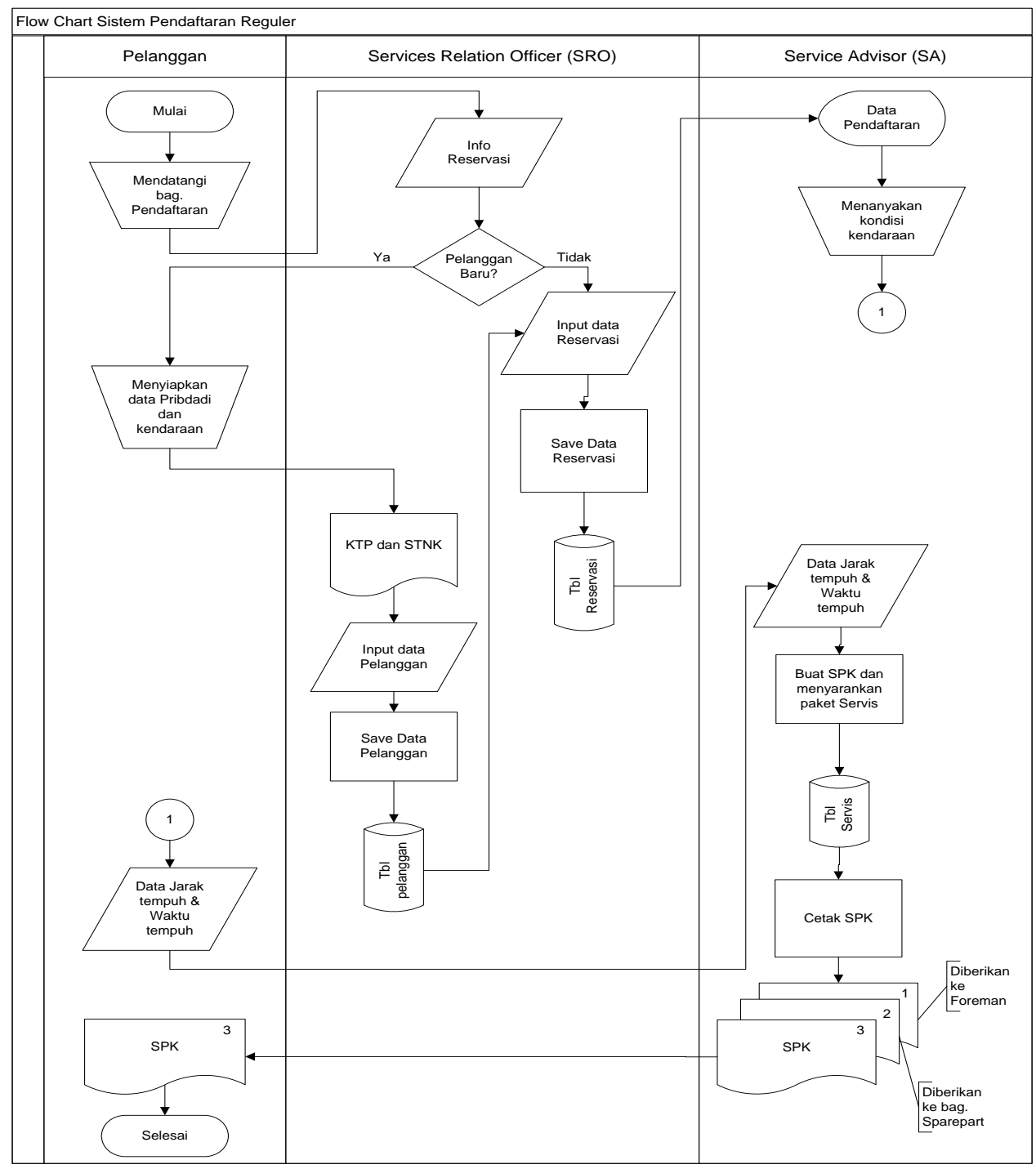

Gambar 2 Diagram Alur Pendaftaran Servis Reguler

\subsection{Prosedur pendaftaran booking servis (Reservasi)}

Pendaftaran secara booking/reservasi merupakan metode lain yang dapat dipilih pelanggan untuk menghindari antrian ketika akan melakukan servis kendaraan. Dengan melakukan reservasi sebelumnya, pelanggan dapat menentukan sendiri waktu servis untuk kendaraannya. Sehingga ketika datang ke lokasi, proses servis kendaraan dapat langsung dilakukan tanpa mengikuti antrian yang ada. Untuk melakukan reservasi, pelanggan bisa datang langsung kebagian pendaftaran, maupun melakukan reservasi melalui layanan telepon. Prosedur pendaftaran reservasi dengan datang langsung ke bagian pendaftaran hampir sama seperti prosedur pendaftaran regular, perbedaan hanya terdapat pada waktu servis. Bagi pendaftar regular, waktu servis mengikuti antrian, sedangkan pada pendaftaran reservasi, waktu pengerjaan servis ditentukan oleh pelanggan. Adapun prosedur pendaftaran reservasi melalui layanan telepon adalah sebagai berikut:

1. Pelanggan menghubungi bagian pendaftaran melalui layanan telepon.

2. Petugas menanyakan status pelanggan. 
a. Untuk pelanggan baru, petugas akan menannyakan nama pelanggan, nomor polisi kendaraan, dan waktu servis yang diinginkan, kemudian dibuatkan memo untuk bagian servis advisor untuk di follow up ketika pelanggan datang.

b. Bagi pelanggan yang sudah terdaftar identitasnya pada sistem, petugas hanya menannyakan nomor polisi kendaraan, dan waktu servis yang diinginkan. Kemudian petugas pendaftaran melakukan input data ke sistem dan memastikan data pelanggan tersebut benar.

3. Pelanggan datang ke lokasi dan menghubungi servis relation officer untuk memberikan kelengkapan data pribadi dan data kendaraan.

4. Servis relation officer menginput data pelanggan baru sekaligus menginput data reservasi pada sistem.

5. Servis advisor memanggil pelanggan secara bergantian, untuk menanyakan kondisi kendaraan kemudian merubah status pendaftaran pada sistem menjadi close (sudah dikerjakan).

6. Servis advisor menanyakan kondisi kendaraan.

7. Servis advisor menyarankan paket servis yang sesuai dengan kondisi kendaraan

8. Servis advisor membuat Surat Perintah Kerja (SPK) sebagai acuan mekanik untuk melakukan servis.

9. SPK yang sudah dibuat dicetak tiga rangkap dan diberikan kepada bagian sparepart, foreman dan pelanggan.

Berikut diagram alur proses pendaftaran servis kendaraan secara reservasi/booking di PT Restu Mahkota Karya: 
Rini Malfiany

Vol 4 No 1

ISSN : 2541-6995

E ISSN : 2580-5517

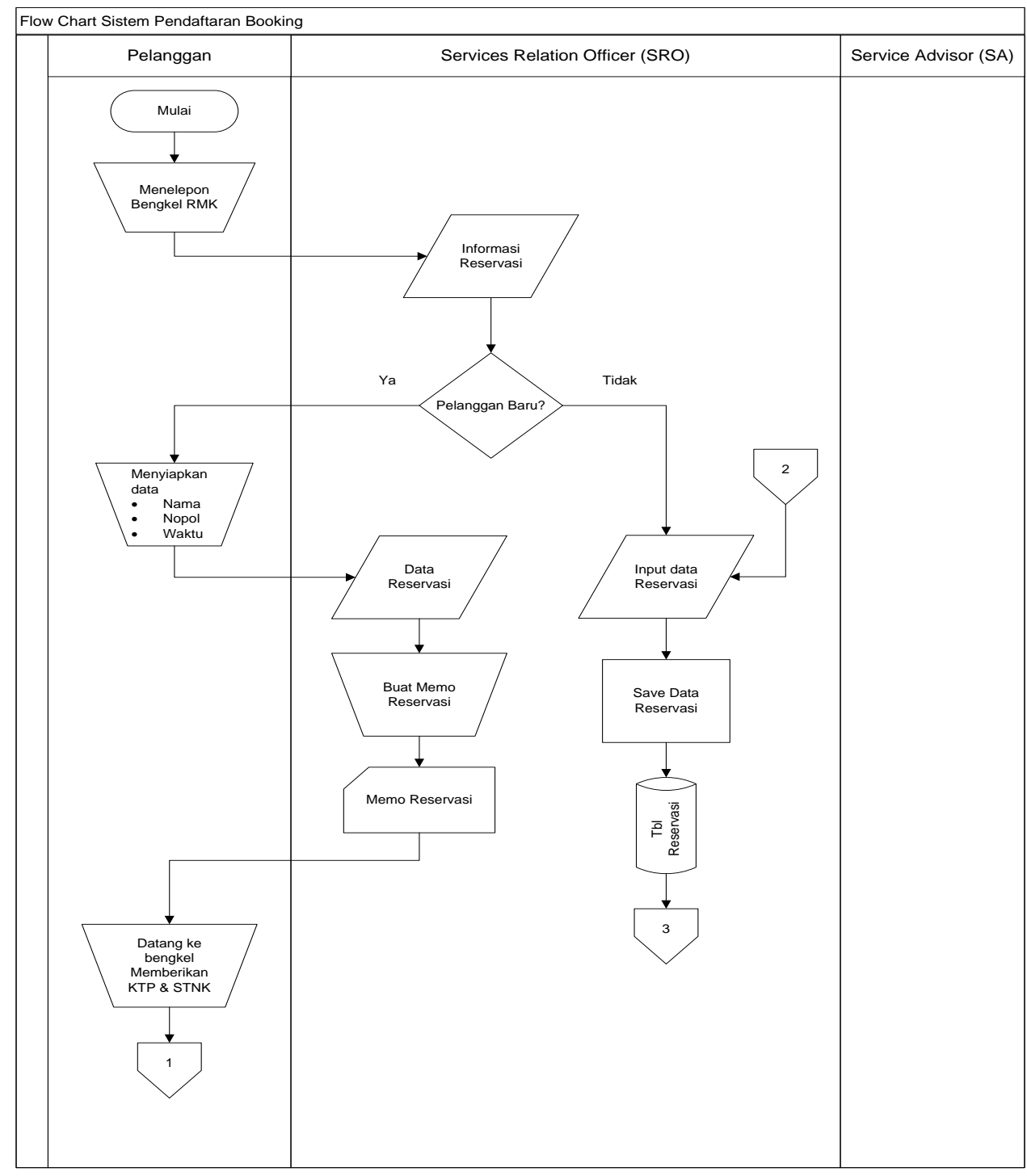

Gambar 3 Diagram Alur Proses Pendaftaran Booking Servis 
ISSN : 2541-6995

E ISSN : 2580-5517

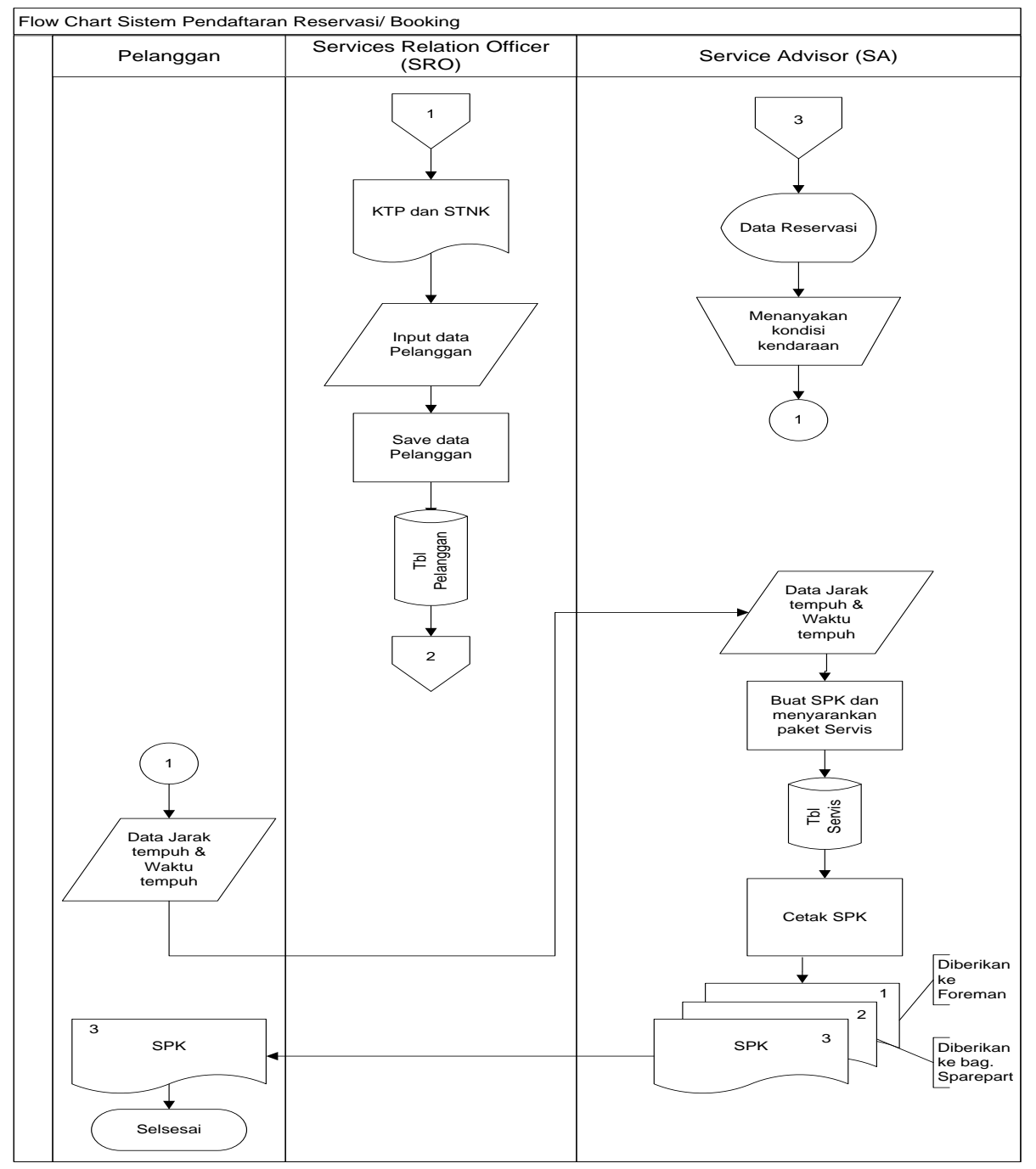

Gambar 4 Lanjutan diagram alur proses pendaftaran booking servis

\subsection{Pemilihan dan Informasi Paket Servis}

Divisi servis pada PT Restu Mahkota Karya melayani servis kendaraan dalam dua kategori, yaitu pelayanan free servis dan servis berkala. Free servis merupakan layanan servis gratis yang dikhususkan bagi kendaraan yang baru dibeli. Sedangkan servis berkala merupakan layanan servis kendaraan yang diberikan pada kendaraankendaraan yang telah lewat dari masa free servis dan dilakukan secara berkala. Terdapat beberapa paket servis berkala yang tersedia ketika melakukan pendaftaran servis. Masing-masing paket menentukan item yang akan di check dan suku cadang yang harus diganti. Paket servis yang tersedia bisa dipilih sesuai dengan jumlah jarak yang sudah ditempuh kendaraan $(/ \mathrm{km})$ atau waktu tempuh $(/ \mathrm{bln})$ kendaraan. Pemilihan paket servis biasanya diberikan oleh servis advisor sesuai dengan kondisi kendaraan, dan informasi mengenai komponen-komponen yang di cek dan suku cadang yang diganti baru didapatkan setelah pelanggan berkonsultasi dengan servis advisor yang bertugas. Setelah mengetahui kondisi kendaraan, dapat ditentukan paket servis yang sesuai dengan kendaraan, setelah itu servis advisor membuatkan surat perintah kerja (SPK) sebagai acuan pengerjaan servis kendaraan yang dilakukan mekanik nantinya. 
Paket servis berkala yang tersedia dibagi menjadi 4, yaitu paket A, Paket B, Paket $\mathrm{C}$, dan paket D. Berikut ini detail informasi mengenai paket servis berkala yang tersedia di PT Restu Mahkota Karya:

1. Servis berkala Paket-A

Servis berkala paket ini diperuntukan bagi kendaraan dengan jarak tempuh $5.000 \mathrm{~km}, 15.000 \mathrm{~km}, 25.000 \mathrm{~km}, 35.000 \mathrm{~km}, 45.000 \mathrm{~km}, 55.000 \mathrm{~km}$, $65.000 \mathrm{~km}, 85.000 \mathrm{~km}$ dan $95.000 \mathrm{~km}$. Penggantian part dan material yang dilakukan ketika melakukan servis berkala paket-A adalah Penggantian oli mesin dan Penggantian filter oli.

Pemeriksaan yang dilakukan meliputi :

a. Pemeriksaan Mesin, yaitu pemeriksaan engine coolant dan pemeriksaan $v$-belt/ rib belt.

b. Pemeriksaan Ignition System dan pemeriksaan Spark plug (busi) termasuk melakukan Penggantian Spark plug bila diperlukan.

c. Pemeriksaan Fuel System, yaitu pemeriksaan dan pembersihan filter udara, pemeriksaan filter bensin dan pemeriksaan fuel line.

d. Pemeriksaan Brake System, yaitu pemeriksaan brake shoe \& Disc pad, pemeriksaan brake pipe/hose (line) dan pemeriksaan cable \& hand brake lever.

e. Pemeriksaan Chassis \& Body, yaitu pemeriksaan pada kopling serta penggantian kopling bila diperlukan, pemeriksaan kondisi roda \& ban, pemeriksaan sistem suspensi, pemeriksaan sistem kemudi, pemeriksaan propeler shaft/ drive shaft, pemeriksaan power steering jika ada, pemeriksaan fungsi instrument panel/ body electric, pemeriksaan karet wiper, pemeriksaan kondisi pintu dan power window, serta pemeriksaan fungsi dan filter elemen AC jika kendaraan dilengkapi komponen tersebut.

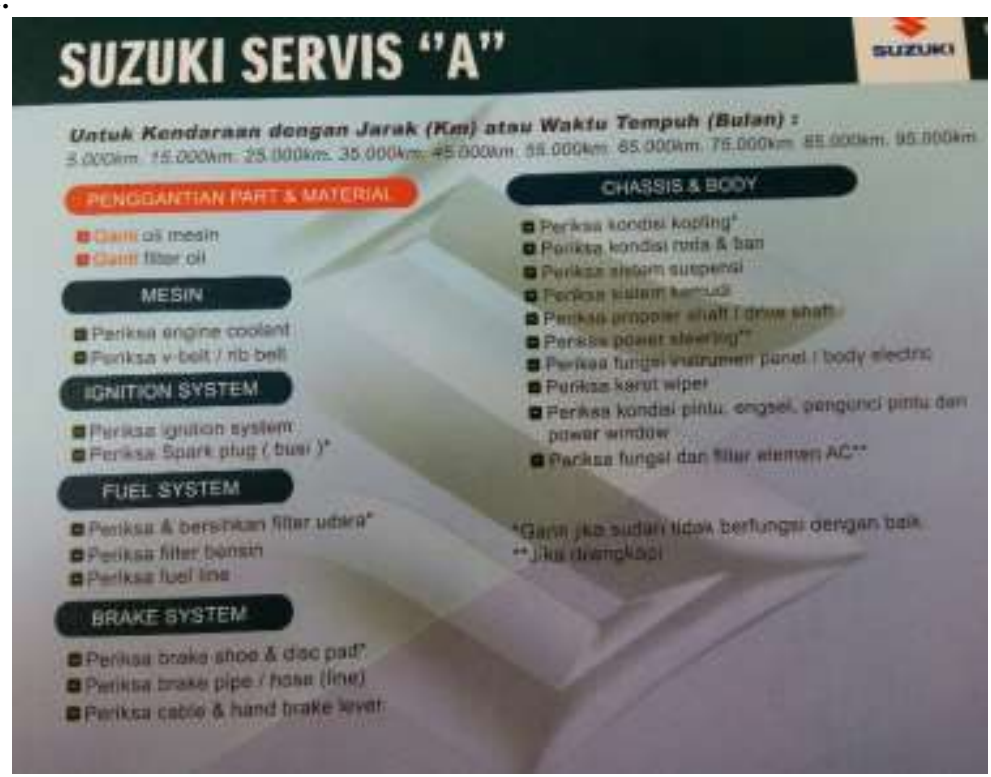

Gambar 5 Ketentuan jenis servis berkala paket A

2. Servis berkala Paket-B

Servis berkala paket ini diperuntukan bagi kendaraan yang memiliki jarak tempuh $(\mathrm{km})$ atau waktu tempuh (bulan) diantaranya $10.000 \mathrm{~km}$ atau 6bulan, 
$30.000 \mathrm{~km}$ atau $18 \mathrm{bulan}, 50.000 \mathrm{~km}$ atau $30 \mathrm{bulan}, 70.000 \mathrm{~km}$ atau $42 \mathrm{bulan}$ dan $90.000 \mathrm{~km}$ atau 54 bulan.

Penggantian part dan material yang dilakukan ketika melakukan servis berkala paket-B adalah penggantian oli mesin dan penggantian filter oil. Adapun pemeriksaan yang dilakukan meliputi :

a. Pemeriksaan Mesin, yaitu pemeriksaan engine coolant, pemeriksaan celah valve, pemeriksaan v-belt/ rib belt, dan pemeriksaan engine mounting.

b. Pemeriksaan Ignition System dan pemeriksaan Spark plug (busi) termasuk melakukan penggantian Spark plug bila diperlukan.

c. Pemeriksaan Emission Control, yaitu memeriksa emisi gas buang.

d. Pemeriksaan Fuel System, yaitu pemeriksaan dan pembersihan filter udara, pemeriksaan filter bensin dan pemeriksaan fuel line.

e. Pemeriksaan Brake System, yaitu pemeriksaan brake shoe \& Disc pad, pemeriksaan brake pipe/hose (line), pemeriksaan cable \& hand brake lever, serta pemeriksaan brake fluid.

f. Pemeriksaan Chassis \& Body, yaitu pemeriksaan pada kopling serta penggantian kopling bila diperlukan, pemeriksaan kondisi roda \& ban, pemeriksaan sistem suspensi, pemeriksaan sistem kemudi, pemeriksaan propeler shaft/ drive shaft, pemeriksaan power steering jika ada, pemeriksaan fungsi instrument panel/ body electric, pemeriksaan karet wiper, pemeriksaan kondisi pintu dan power window, serta pemeriksaan fungsi dan filter elemen AC jika kendaraan dilengkapi komponen tersebut.

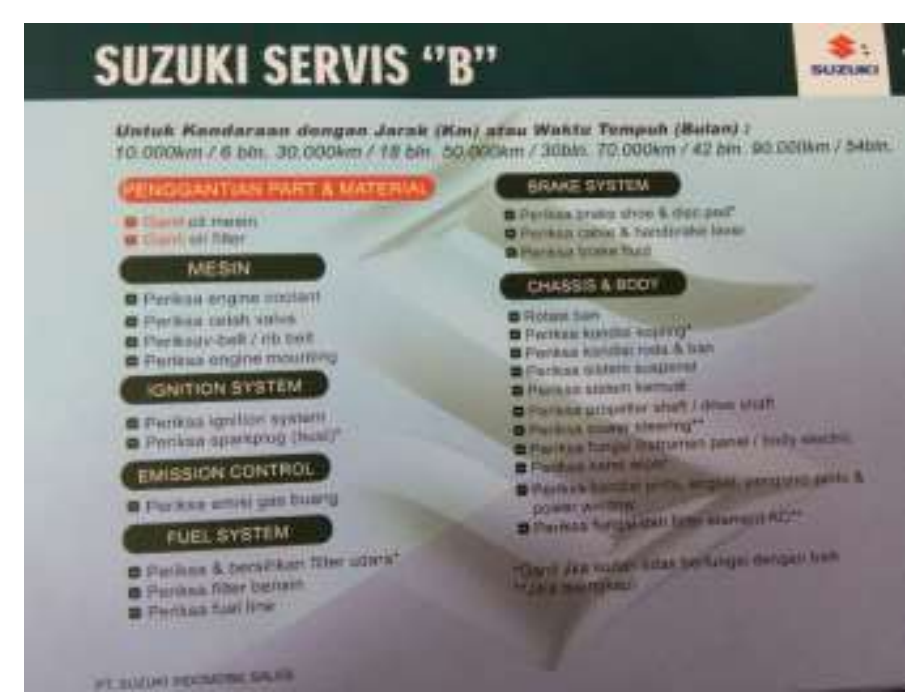

3. Servis berkala Paket $-\mathrm{C}$

Gambar 6 Ketentuan jenis servis berkala paket B

Servis berkala paket ini diperuntukan bagi kendaraan yang memiliki jarak tempuh $(\mathrm{km})$ atau waktu tempuh (bulan) diantaranya $20.000 \mathrm{~km}$ atau 12bulan, $60.000 \mathrm{~km}$ atau $36 \mathrm{bulan}$, dan $100.000 \mathrm{~km}$ atau $60 \mathrm{bulan}$.

Penggantian part dan material yang dilakukan ketika melakukan servis berkala paket-C adalah penggantian oli mesin, penggantian oli filter, penggantian Spark plug (busi), penggantian oli transmisi, serta penggantian 
oli differensial jika kendaraan menggunakan maerial tersebut. Adapun pemeriksaan yang dilakukan meliputi :

a. Pemeriksaan Mesin, yaitu pemeriksaan engine coolant, pemeriksaan timing belt, pemeriksaan celah valve, pemeriksaan nut/ bolt manifold, pemeriksaan $v$-belt/ rib belt, dan pemeriksaan engine mounting.

b. Pemeriksaan Ignition System, yaitu pemeriksaan ignition timing.

c. Pemeriksaan Emission Control, yaitu pemeriksaan valve PCV, pemeriksaan fuel evaporation system, serta memeriksa emisi gas buang.

d. Pemeriksaan Fuel System, yaitu pemeriksaan dan pembersihan filter udara, pemeriksaan filter bensin dan pemeriksaan fuel line.

e. Pemeriksaan Brake System, yaitu pemeriksaan brake shoe \& Disc pad, pemeriksaan brake pipe/hose (line), pemeriksaan cable \& hand brake lever, serta pemeriksaan brake fluid.

f. Pemeriksaan Chassis \& Body, yaitu pemeriksaan rotasi ban, pemeriksaan pada kopling serta penggantian kopling bila diperlukan, pemeriksaan kondisi roda \& ban, pemeriksaan sistem suspensi, pemeriksaan sistem kemudi, pemeriksaan propeler shaft/ drive shaft, Pemeriksaan A/T Fluid jika ada, pemeriksaan power steering jika ada, pemeriksaan fungsi instrument panel/ body electric, pemeriksaan karet wiper, pemeriksaan kondisi pintu dan power window, serta pemeriksaan fungsi dan filter elemen AC jika kendaraan dilengkapi komponen tersebut.

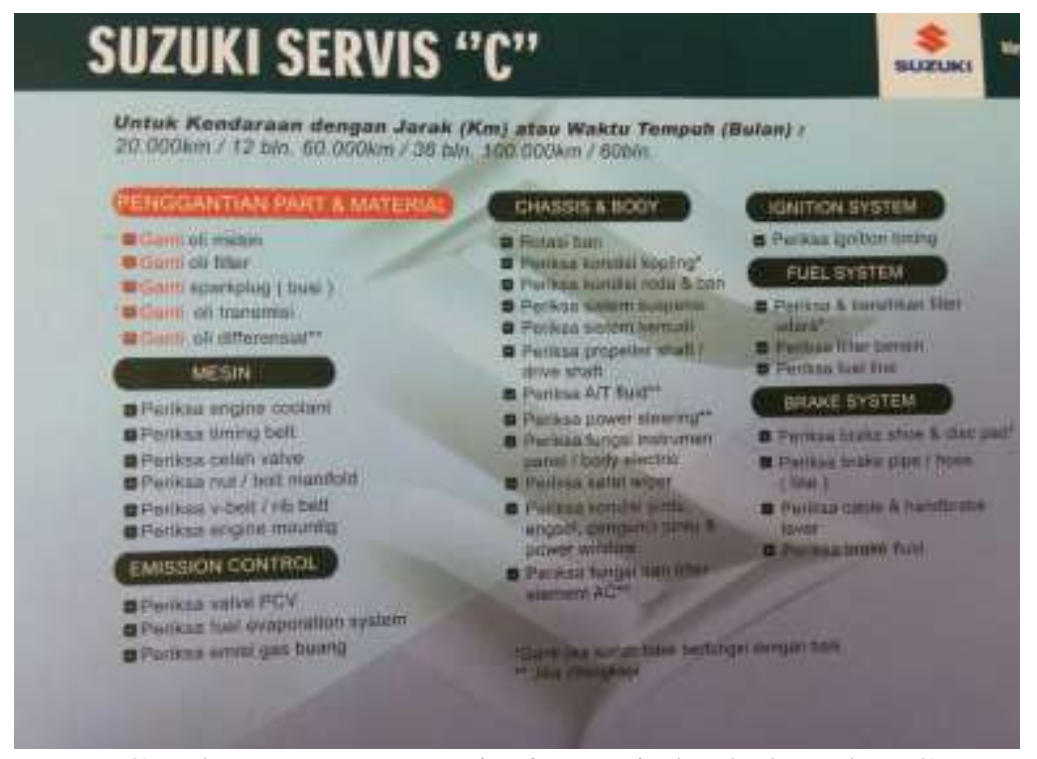

Gambar 7 Ketentuan jenis servis berkala paket C

4. Servis berkala Paket $-\mathrm{D}$

Servis berkala paket ini diperuntukan bagi kendaraan yang memiliki jarak tempuh $(\mathrm{km})$ atau waktu tempuh (bulan) diantaranya $40.000 \mathrm{~km}$ atau 24bulan, dan $80.000 \mathrm{~km}$ atau 48 bulan.

Penggantian part dan material yang dilakukan ketika melakukan servis berkala paket-D adalah penggantian oli mesin, penggantian filter oli, penggantian filter elemen AC jika ada, penggantian filter udara, serta penggantian engine coolant, penggantian spark plug (busi), penggantian oli 
transmisi, serta penggantian oli differensial jika kendaraan menggunakan material tersebut. Adapun pemeriksaan yang dilakukan meliputi :

a. Pemeriksaan Mesin, yaitu pemeriksaan timing belt, pemeriksaan celah valve, pemeriksaan nut/ bolt manifold, pemeriksaan v-belt/ rib belt termasuk melakukan penggantian part apabila diperlukan, dan pemeriksaan engine mounting.

b. Pemeriksaan Ignition System, yaitu pemeriksaan ignition timing.

c. Pemeriksaan Emission Control, yaitu pemeriksaan valve PCV, pemeriksaan fuel evaporation system, serta memeriksa emisi gas buang.

d. Pemeriksaan Fuel System, yaitu pemeriksaan filter bensin dan melakukan penggantian apabila diperlukan, serta pemeriksaan fuel line.

e. Pemeriksaan Brake System, yaitu pemeriksaan brake shoe \& Disc pad dan melakukan penggantian part dika diperlukan, pemeriksaan brake pipe/hose (line), serta pemeriksaan cable \& hand brake lever.

f. Pemeriksaan Chassis \& Body, yaitu pemeriksaan rotasi ban, pemeriksaan pada kopling serta penggantian kopling bila diperlukan, pemeriksaan kondisi roda \& ban, pemeriksaan sistem suspensi, pemeriksaan sistem kemudi, pemeriksaan propeler shaft/ drive shaft, pemeriksaan power steering jika ada, pemeriksaan fungsi instrument panel/ body electric, pemeriksaan karet wiper, serta pemeriksaan kondisi pintu dan power window.

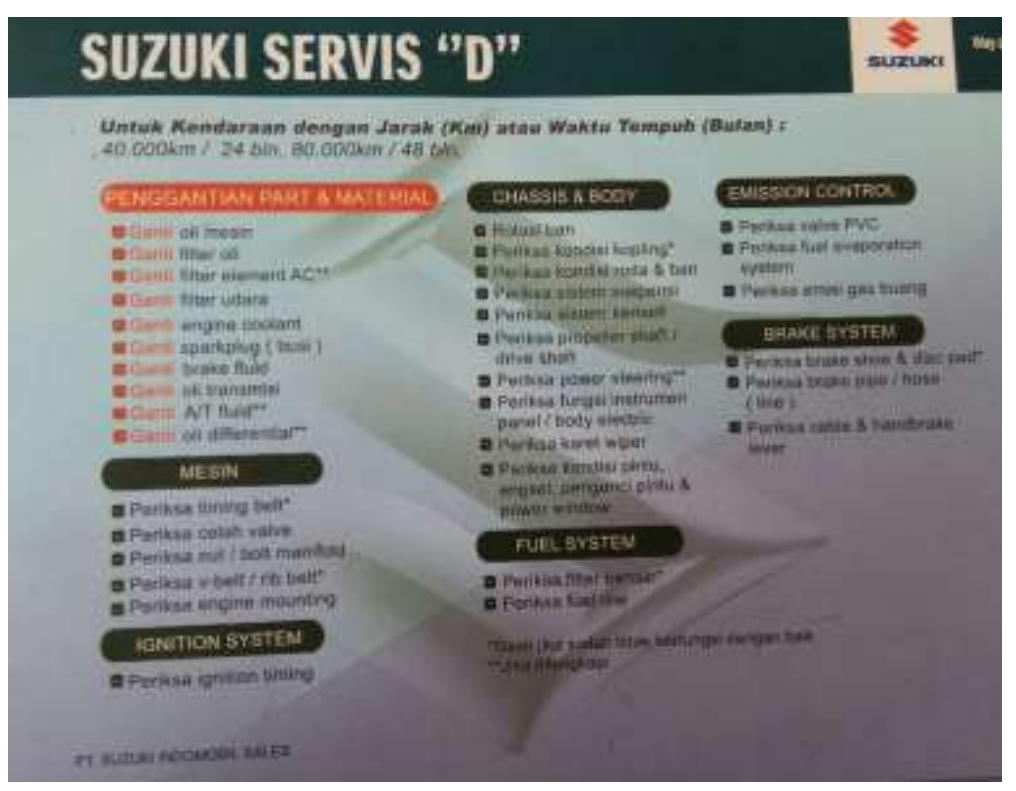

Gambar 8 Kententuan jenis servis berkala paket D 
Berdasarkan ketentuan-ketentuan jenis paket servis yang sudah diuraikan diatas, tentunya terdapat perbedaan biaya yang dikenakan untuk setiap paket servis, adapun daftar harga servis berkala sesuai dengan paket dan jenis kendaraannya yaitu sebagai berikut:

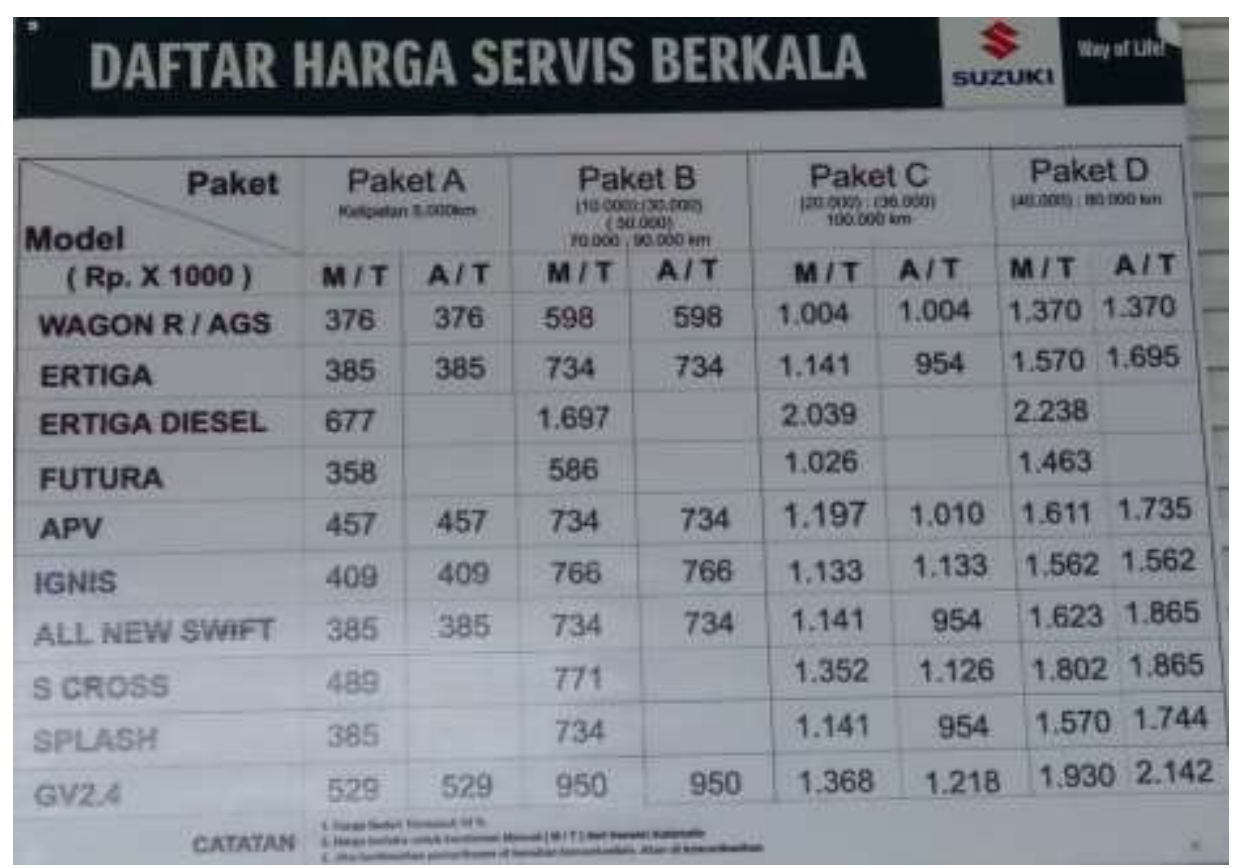

Gambar 9 Daftar Harga Servis Berkala

\section{KESIMPULAN}

Kesimpulan yang dapat penulis ambil dari penelitian yang dilaksanakan pada PT Restu Mahkota Karya Cabang Karawang adalah sebagai berikut:

1. PT Restu Mahkota Karya sebagai dealer resmi Suzuki di kabupaten Karawang sudah memiliki sistem informasi servis kendaraan sendiri yang terhubung ke berbagai cabang perusahaan di kota-kota lainnya dalam sistem aplikasi berbasis web.

2. PT Restu Mahkota Karya melayani servis kendaraan dalam 2 kategori, yaitu free servis dan servis berkala, yang dalam pelaksanaannya terbagi menjadi 4 paket servis yaitu paket-A, paket-B, paket-C dan paket-D yang ditentukan sesuai dengan kondisi kendaraan.

3. Dalam pelaksanaannya, pelanggan yang akan melakukan servis kendaraan harus mendaftarkan kendaraannya terlebih dahulu. Ada dua metode pendaftaran yang dapat diambil pelanggan untuk melakukan servis kendaraan, yaitu dengan datang langsung ke bagian pendaftaran atau melakukan booking melalui layanan telepon.

4. Pada sistem pendaftaran yang sedang berjalan, terdapat beberapa kekurangan yang harus diperbaiki untuk meningkatkan kepuasan pelanggan dalam melakukan servis kendaraan di PT Restu Mahkota Karya, seperti waktu pendafataran yang terbatas jam kerja yaitu pukul $09.00 \mathrm{~s} / \mathrm{d} 17.00$, sistem pendaftaran untuk pelanggan baru yang masih kurang efektif dan membebankan bagian lain, dan informasi paket servis beserta ketentuannya belum bisa tersampaikan dengan jelas kepada pelanggan. 
5. Dengan sistem informasi monitoring yang diusulkan pelanggan dapat mengetahui sistem yang berjalan mengenai penyampaian informasi perkembangan proses servis yang berlangsung mulai dari pendaftaran sampai penyerahan kendaraan kepada pelanggan.

\section{DAFTAR PUSTAKA}

As, Mahmoeddin. (2010). Melacak Kredit Bermasalah. Jakarta: Pustaka Sinar Harapan.

Buana, I Komang Setia. (2014). Jago Pemrograman PHP. Jakarta: Dunia Komputer. DEPDIKBUD01. (2012). Sesi Pendaftaran Siswa Baru.

Djiwandono, Patrisius Istiarto. (2015). Meneliti itu tidak sulit: metodologi peneltian social dan pendidikan bahasa". Yogyakarta:Deepublish.

Fathansyah. (2012). Basis Data (Edisi Revisi). Bandung: Informatika.

Hutahaean, Japerson. (2014). "Konsep Sistem Informasi”. Yogyakarta: Deepublish.

Indrajani. (2011). Perancangan Basis Data dalam All in 1. Jakarta: PT Elex Media Komputindo.

Jogiyanto. (2010). Analisis dan Desain Sistem Informasi. Yogyakarta: Andi.

Kadir, Abdul. (2014). Pengenalan Sistem Informasi Edisi Revisi. Yogyakarta: Andi.

Kristanto, Andri. (2010). Perancangan Sistem dan Aplikasi. Yogyakarta: Gava Media.

Kustiyahningsih, Yeni., R.A. Devie. (2011). Pemrograman Basis Data Berbasis Web menggunakan PHP \& MySQL, Edisi Pertama. Yogyakarta: Graha Ilmu.

Lubis, Adyanata. (2016). "Basis Data Dasar". Yogyakarta: Deepublish

Madcoms. (2010). Aplikasi Program PHP + MySQL untuk Membuat Website Interaktif. Yogyakarta: Andi.

Madcoms. (2011). Aplikasi Web Database dengan Dreamweaver dan PHP MySQL. Yogyakarta: Andi.

Marisa, Fitri. (2016). “Web Programming (Client Side And Server Side)”. Yogyakarta: Deepublish

Mulyani, Sri. (2016)“Metode Analisis dan Perancangan Sistem”.bandung:abdi sistematika.

Mustakini, Jogiyanto Hartono. (2010). Analisa Sistem Informasi, Edisi III. Yogyakarta: Andi.

Nidhra, Srinivas, \& Dondeti, Jagruthi. (2012). Black Box and White Box Testing Techniques-A Literature Review. International Journal of Embedded Systems and Aplications (IJESA), 2(2), 1-2.

Nugroho, Bunafit. (2013). "Dasar Pemrograman Web PHP - MySQL dengan Dreamweaver". Yogyakarta: Gava Media.

Pamungkas, Canggih Ajika. (2017). Pengantar dan Implementasi Basis Data. Yogyakarta: Deepublish.

Pressman, Roger S. (2012). Rekayasa Perangkat Lunak Pendekatan Praktisi (Edisi 7). Yogyakarta: Andi.

Ramadhan, Mochammad Reza, Lukito Edi Nugroho dan Selo Sulistyo (2017). Perancangan Sistem Informasi Monitoring Skripsi. ISSN: 2085-6350. Yogyakarta, 27 Juli 2017. CITEE Departemen Teknik Elektro dan Teknologi Informasi, FT UGM. Hal 290-295.

Rente, Rintho Rerung. (2018). Pemrograman Web Dasar. Yogyakarta: Deepublish. 
Rosa dan salahudin. (2011). Modul Pembelajaran Rekayasa Perangkat Lunak. Bandung: Modula.

Rudyanto, Arief. (2011). Pemrograman Web Dinamis menggunakan PHP dan MySQL. Yogyakarta: Andi.

Saputra, Agus. (2012). Webtips : PHP, HTML5, dan CSS3. Jakarta: Jasakom.

Satzinger, John W, Robert B. Jackson, Stephen D. Burd. (2012). Introduction To Systems Analys And Design: An Agile, Interative Approach (Paperback).

Sitorus, Lamhot. (2015). “Algoritma dan Pemrograman”. Yogyakarta:Andi.

Siyoto, Sandu dan Supriyanto. (2015). Kebijakan Dan Manajemen Kesehatan. Yogyakarta: Andi

Solichin, achmad. (2016). Pemrograman Web dengan PHP dan MySQL. Jakarta: Universitas Budi Luhur.

Subhan, Mohamad. (2012). Analisa Perancangan Sistem. Jakarta: Lentera Ilmu Cendekia.

Sutabri, Tata. (2012). Konsep Sistem Informasi. Yogyakarta: Andi

Sutarman. (2012). Pengantar Teknologi Informasi. Jakarta: Bumi Aksara.

Yakub. (2012). Pengantar Sistem Informasi. Yogyakarta: Graha Ilmu. 